\title{
Hubungan Filogenetik Intraspesies Cucumis melo L. berdasarkan DNA Barcode Gen matK
}

\author{
Intraspecies Phylogenetic Relationship of Cucumis melo L. based on DNA Barcode Gen \\ matK
}

\author{
Dewi Retnaningati \\ Fakultas Teknobiologi, Univertas Atma Jaya Yogyakarta, Daerah Istimewa Yogyakarta \\ E-mail:dewiretna13@gmail.com
}

\begin{abstract}
The reconstruction of the evolutionary relationship from groups of biological organisms, like the phylogenetic relationship, is one of the most important things in systematic review. A wellreconstructed evolutionary relationship can be used as a basis for conducting comparative studies. The basic idea of using DNA sequences in the study of phylogenetics (DNA Barcode) is that there is a change of nucleotide base by time, so that the rate of evolution that occurs can be predicted and the evolutionary relationship between one group of organisms with another can be reconstructed. DNA barcode is an identification method of a new species that is accurate, rapid, and automatic, using a short sequence of genomic DNA. Maturase $K$ gene (matK) of chloroplast is highly conserved in plant systematics which is involved in Group-II intron splicing. MatK gene is a popular gene used in DNA Barcode of plants in the world, hence the construction of DNA barcodes based on MatK gene is expected to show the specific molecular characteristics of the melon. The matK gene sequences have been withdrawn from GenBank and used for the analysis. The multiple sequence alignments were performed by GenebeeClustalW. The phylogenetic analyses were carried out by MEGA (Molecular Evolutionary Genetics Analysis) software package based on Maximum Parsimony (MP) methods. The matK gene in melon contains more $A$ and $T$ bases than the $G$ and $C$ bases. The analysis result shows there are 43 varietive sites and 6 Parsimony sites from 576 bp in lenght of matK gene are alligmented. The consistency index is $(0.777778)$, the retention index is $(0.777778)$, and the composite index is $\mathbf{0 . 7 4 4 6 8 1}(\mathbf{0 . 6 0 4 9 3 8})$ for all sites and parsimony-informative sites (in parentheses). Genus Cucumis is a monophyletic group. Analysis of molecular character based on DNA barcode of matK gene shows that this gene is able to distinguish intraspesies variations in melon.
\end{abstract}

Key words:phylogenetic relationship, Cucumis melo L., molecular characters, DNA Barcodes, MatK gene

\section{Abstrak}

Rekonstruksi hubungan evolusi (evolutionary relationship) dari kelompok organisme, salah satunya yaitu hubungan filogenetik, merupakan hal penting dalam kajian sistematika yang dapat digunakan sebagai landasan untuk melakukan penelitian-penelitian komparatif. Pemikiran dasar penggunaan sekuen DNA dalam studi filogenetika (DNA Barcode) adalah bahwa terjadi perubahan basa nukleotida menurut waktu, sehingga akan dapat diperkirakan kecepatan evolusi yang terjadi dan akan dapat direkonstruksi hubungan evolusi antara satu kelompok organisme dengan yang lainnya. Gen $M a t K$ adalah gen populer yang digunakan dalam DNA Barcode tanaman di dunia, maka penyusunan DNA barcode berdasarkan gen MatK diharapkan dapat menunjukkan karakter molekuler yang spesifik dari melon. Analisis filogenetik dilakukan oleh paket perangkat lunak MEGA (Molecular Evolutionary Genetics Analysis) berdasarkan metode Maximum Parsimony (MP). Gen matK dalam melon mengandung lebih banyak basa $A$ dan $T$ daripada basa $G$ dan $C$. Hasil analisis menunjukkan ada 43 situs variatif dan 6 situs Parsimony dari 576 bp gen matK yang diaggregasi. Indeks konsistensi adalah $(0,777778)$, indeks retensi adalah $(0,777778)$, dan indeks komposit adalah $0,744681(0,604938)$ untuk semua situs dan situs parsimoni-informatif (dalam kurung). Genus Cucumis adalah kelompok monofiletik. Analisis karakter molekuler berdasarkan barcode DNA 
dari gen matK menunjukkan bahwa gen ini mampu membedakan variasi intraspesies dalam melon.

Kata kunci: hubungan filogenetik, Cucumis melo L., karakter molekuler, DNA Barcode, gen MatK

Diterima: 16 Maret 2017, disetujui: 30 April 2017

\section{Pendahuluan}

Salah satu tugas penting dari sistematika adalah merekonstruksi hubungan evolusi (evolutionary relationship) dari kelompokkelompok organisme biologi. Sebuah hubungan evolusi yang direkonstruksi dengan baik dapat digunakan sebagai landasan untuk melakukan penelitian-penelitian komparatif (comparative investigations) misalnya dalam bidang ekologi dan biogeografi. Ada dua metode untuk merekonstruksi hubungan evolusi dari sebuah kelompok organisme biologi, yaitu fenetika dan kladistika. Kladistika sering disebut atau ditulis di dalam literatur ilmiah sebagai filogenetika dan merupakan metode yang umum digunakan di dalam banyak penelitian sistematika. Pemikiran dasar penggunaan sekuen DNA dalam studi filogenetika (DNA Barcode) adalah bahwa terjadi perubahan basa nukleotida menurut waktu, sehingga akan dapat diperkirakan kecepatan evolusi yang terjadi dan akan dapat direkonstruksi hubungan evolusi antara satu kelompok organisme dengan yang lainnya (Hidayat, 2008).

Beberapa alasan penggunaan sekuen DNA (DNA Barcode) yaitu (1) DNA merupakan unit dasar informasi yang mengkode organisme, (2) lebih memudahkan dalam mengekstrak dan menggabungkan informasi mengenai proses evolusi suatu kelompok organisme, sehingga mudah untuk dianalisis, (3) memudahkan dalam pembuatan model dari peristiwa evolusi secara komparatif, dan (4) menghasilkan informasi yang banyak dan beragam, dengan demikian akan ada banyak bukti tentang kebenaran suatu hubungan filogenetika (Hillis dkk., 1996). Paling sedikit ada tiga tahap penting dalam analisis filogenetika molekuler, yaitu sequence alignment, rekonstruksi pohon filogenetika, dan evaluasi pohon filogenetika. Data sekuen DNA dapat diperoleh dari sumber database molekuler di GenBank ataupun dari hasil sekuensing (Hidayat, 2008).

Penelitian Kolondam dkk., (2012) mengenai DNA Barcode gen matK melaporkan bahwa Barcode matK memiliki kemampuan pembeda yang lebih baik untuk identifikasi sampel dalam penelitian variasi intraspesies. Kecepatan mutasi pada gen matK memegang peranan penting dalam variasi intraspesifik. Gen matK merupakan salah satu dari coding gene yang paling variatif pada Angiospermae sehingga gen ini dijadikan barcode untuk tanaman darat. Sebagai coding gene, laju evolusi gen $m a t K$ yang sangat tinggi menjadikan gen ini dapat digunakan dalam rekonstruksi filogenetik pada tingkatan taksonomi Bangsa dan Suku, dan kadang juga digunakan pada tingkatan taksonomi Marga, Spesies, dan subspesies (Jing dkk., 2011). Secara umum DNA Barcode memiliki fungsi aplikatif yaitu untuk survei ekologi (Dick dan Kress, 2009), identifikasi takson-takson kriptik (Lahaye dkk., 2008), dan konfirmasi sampel-sampel tanaman obat (Xue dan Li, 2011).

Analisis filogenetik pada tanaman menjadi informasi yang penting untuk aplikasi praktik hibridisasi, salah satunya yaitu pada tanaman melon. Melon (Cucumis melo L.) digunakan sebagai buah, tapi buah yang belum matang digunakan sebagai sayuran, biji dapat dimakan dan akar dapat digunakan dalam pengobatan (Robinson dan Decker Walters, 1997; Nayar dan Sing, 1998). Melon merupakan buah yang memiliki nilai komersial tinggi di Indonesia dengan kisaran pasar yang luas dan beragam. Hal ini menunjukkan bahwa komoditas melon sangat potensial untuk diusahakan karena memiliki daya saing dibandingkan komoditas buah lainnya (Sobir \& Siregar, 2010). Melon telah dibudidayakan di China sejak 2000 tahun SM (Keng, 1974) dan banyak kultivar dan tingginya keragaman buah telah ditingkatkan sebagaimana penyebaran bentuk budidaya/ 
kultivarnya di seluruh dunia di daerah tropis dan subtropis. Analisis filogenetik pada tanaman, termasuk melon dapat diolah berdasarkan pada karakter gen penanda, yaitu gen $m a t K$.

\section{Metode Penelitian}

\section{Koleksi Data}

Informasi genetik dan spesies diperoleh dari National Centre for Biotechnology Information (NCBI). Seluruh kultivar spesies Cucumis melo L. yang data sekuen gen matK'nya tersedia di GenBank disajikan pada Tabel 1.

\section{Analisis Sekuen}

Urutan basa DNA gen matK dari berbagai kultivar melon yang sudah terdata di GenBank disejajarkan dengan menggunakan program ClustalX untuk menemukan statistik urutan dasar termasuk komposisi nukleotida dan variabilitas di berbagai area pada sekuen gen.

\section{Penyusunan pohon filogenetik}

Karakter-karakter hasil penjajaran urutan basa DNA, selanjutnya dilakukan analisis filogenetik dengan mengkonstruksi pohon filogenetik berdasarkan sekuen gen matK menggunakan metode Maximum Parsimony yang dilakukan dengan menggunakan program MEGA 5.2 (Tamura dkk., 2011). Evaluasi pohon filogenetik dilakukan dengan menggunakan metode bootstrap sebanyak ulangan.

\section{Hasil dan Pembahasan}

Pengumpulan data sekuen gen matK yang dikoleksi dari GenBank (database NCBI). Data yang didapatkan dari GenBank yaitu sebanyak 10 sekuen gen matK dari 10 kultivar Cucumis melo L. Daftar nama kultivar ditampilkan pada Tabel 1.

Dari data molekuler yang sudah dikoleksi dilakukan analisis sekuen dengan melakukan penyejajaran (alignment) menggunakan program ClustalX (Gambar 1). Penyejajaran dilakukan dengan tujuan untuk menentukan tingkat homologi dari urutan basa DNA yang dianalisis serta menemukan statistik urutan dasar termasuk komposisi nukleotida dan variabilitas di berbagai area pada sekuen gen.

Hasil penjajaran menunjukkan bahwa sampel-sampel yang diteliti memiliki tingkat homologi yang tinggi. Terdapatnya gap menunjukkan terjadinya proses mutasi berupa insersi maupun delesi. Dari 576 bp sekuen gen mat $K$ yang disejajarkan, terdapat 43 posisi yang variatif dan 6 posisi yang Parsimony. Sementara itu persentase komposisi basa Nitrogen pada setiap sekuen gen matK masing-masing kultivar ditunjukkan pada Tabel 2.

Analisis pohon filogenetik menggunakan metode maximum parsimony (MP) merupakan cara untuk merekonstruksi pohon filogenetik berdasarkan jumlah perubahan (evolusi) terkecil. Hasil aligment sekuen gen matK dari beberapa kultivar Cucumis melo L. dengan panjang sekuen yang digunakan untuk merekonstruksi pohon filogenetik yaitu $576 \mathrm{bp}$ menunjukkan ada 6 posisi/situs parsimony-informative, yaitu situs yang menunjukkan adanya perbedaan jumlah substitusi pada pola percabangan kladogram untuk menjelaskan variasi pada situs tersebut yang terjadi karena evolusi dalam jangka waktu yang panjang (Farris 1989). Indeks konsistensi sebesar 0,777778, indeks retensi sebesar 0,777778 dan indeks komposit sebesar 0,744681 untuk semua situs dan situs parsimonyinformative. Rekonstruksi pohon filogenetik menggunakan outgroup yaitu Cucumis sativus.

Pohon Filogenetik dengan metode $M P$ yang dihasilkan (Gambar 2) menunjukkan bahwa genus Cucumis merupakan kelompok monofiletik yaitu berasal dari nenek moyang yang sama (Mukherjee, 1953). Pohon filogenetik tersebut memperlihatkan bahwa beberapa sampel kultivar melon terbagi menjadi lima kelompok/clade besar, yaitu kelompok/clade pertama yang beranggotakan kultivar Pudukkottai, kelompok/clade kedua kedua beranggotakan kultivar Theni, kelompok/clade ketiga beranggotakan kultivar Marakkam, kelompok/clade keempat beranggotakan kultivar Andaman dan N-78, dan kelompok/clade kelima beranggotakan 6 kultivar lainnya dan terbagi menjadi lima subclade. Subclade pertama beranggotakan kultivar Mayilam, Subclade kedua beranggotakan kultivar Olakkur, Subclade ketiga beranggotakan kultivar CM-1, Subclade keempat beranggotakan kultivar CM-2, dan 
Subclade kelima beranggotakan kultivar Muksmelon Orange dan Mysore. Panjang cabang (branch lenght) pada mewakili jumlah perubahan yang terjadi pada cabang. Branch lenght pada pohon filogenetik menggambarkan seberapa jauh/dekat kekerabatan antar kultivar. Semakin panjang branch lenght-nya berarti kekerabatan antar kultivar semakin jauh. Penggunaan DNA barcode berdasarkan gen matK mampu membedakan variasi intraspesies pada tanaman melon.

Analisis filogenetik pada tanaman menjadi informasi yang penting untuk aplikasi praktik hibridisasi (plant breeding). Oleh karena dalam hibridisasi terjadi penggabungan dua atau lebih sifat dari jenis tanaman yang berbeda, maka prasyaratnya adalah tanaman-tanaman tersebut harus memiliki pola genetik yang sama (Frowine 2005), sehingga memiliki kecenderungan untuk menjalani jalur evolusi yang sama (Li dan Graur 1991). Dengan kata lain bahwa tanamantanaman yang akan dihibridisasi harus memiliki hubungan evolusi atau kekerabatan (filogenetika) yang dekat. Dalam konteks filogenetika, tanaman-tanaman ini harus memiliki hubungan monofiletik, yaitu berasal dari satu nenek moyang yang sama. Sebaliknya, jika hubungan kekerabatan tanaman-tanaman yang akan dihibridisasi adalah non monofiletik maka salah satu yang timbul adalah reaksi penolakan karena tidak ada kecocokan genetik seperti yang sering terjadi dalam banyak kegiatan hibridisasi (Frowine 2005).

Tabel 1. Data sampel kultivar melon (Cucumis melo L.) dari GenBank

\begin{tabular}{clccc}
\hline No & Nama Kultivar & GenBank Accession Number & Panjang sekuen (bp) & Referensi \\
\hline 1 & CM-2 & JN003875.1 & 576 & Prathap,A., 2011 \\
2 & CM-1 & JN003874.1 & 576 & Prathap,A., 2011 \\
3 & Mayilam & JN003873.1 & 576 & Prathap,A., 2011 \\
4 & Marakkanam & JN003872.1 & 576 & Prathap,A., 2011 \\
5 & Muksmelon Orange & JN003871.1 & 576 & Prathap,A., 2011 \\
6 & Theni & JN003870.1 & 576 & Prathap,A., 2011 \\
7 & Pudukkottai & JN003869.1 & 576 & Prathap,A., 2011 \\
8 & Olakkur & JN003868.1 & 576 & Prathap,A., 2011 \\
9 & N-78 & JN003867.1 & 576 & Prathap,A., 2011 \\
10 & Mysore & JN003866.1 & 576 & Prathap,A., 2011 \\
11 & Andaman & JN003865.1 & 576 & Prathap,A., 2011 \\
\hline
\end{tabular}

Tabel 2. Tabel persentase komposisi basa nitrogen gen mat $K$ dari masing-masing sampel kultivar melon

\begin{tabular}{lccccc} 
Nama Kultivar & T(U) & C & A & G & Total \\
\hline CM-2 & 29,7 & 16,7 & 36,6 & 17,0 & 576,0 \\
CM-1 & 29,7 & 16,7 & 36,6 & 17,0 & 576,0 \\
Mayilam & 29,7 & 16,8 & 36,1 & 17,4 & 576,0 \\
Marakkanam & 29,7 & 16,5 & 36,6 & 17,2 & 576,0 \\
Theni & 29,7 & 16,5 & 36,6 & 17,2 & 576,0 \\
Muskmelon Orange & 29,2 & 18,1 & 35,2 & 17,5 & 576,0 \\
Pudukkottai & 29,7 & 16,5 & 36,6 & 17,2 & 576,0 \\
Olakkur & 29,7 & 16,7 & 36,3 & 17,4 & 576,0 \\
N - 78 & 30,0 & 16,3 & 36,3 & 17,4 & 576,0 \\
Mysore & 29,5 & 17,0 & 36,1 & 17,4 & 576,0 \\
Rata-rata & 29,6 & 16,8 & 36,3 & 17,3 & 576,0 \\
\hline
\end{tabular}




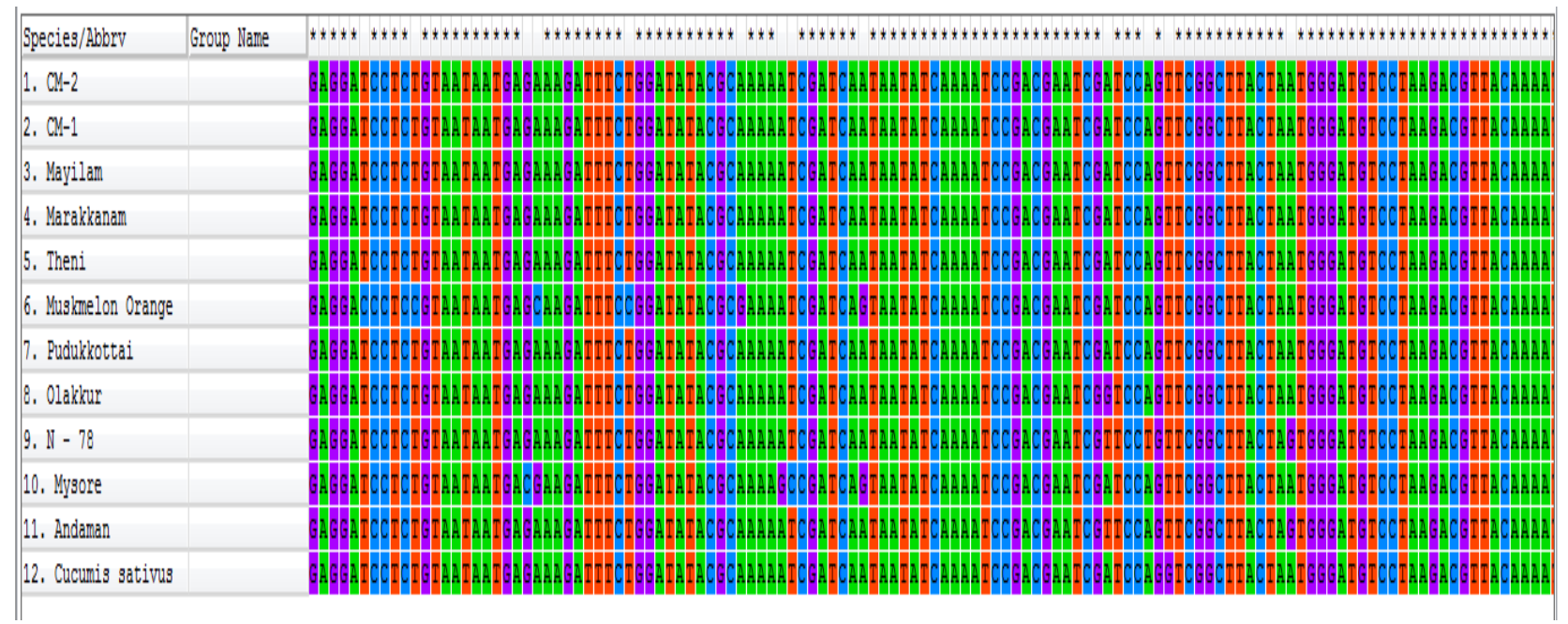

Gambar 1. Hasil Alignment gen matK Cucumis melo L. pada berbagai kultivar melon.10 jenis kultivar melon sebagai ingroup dan spesies lain yaitu Cucumis sativus sebagai outgroup.

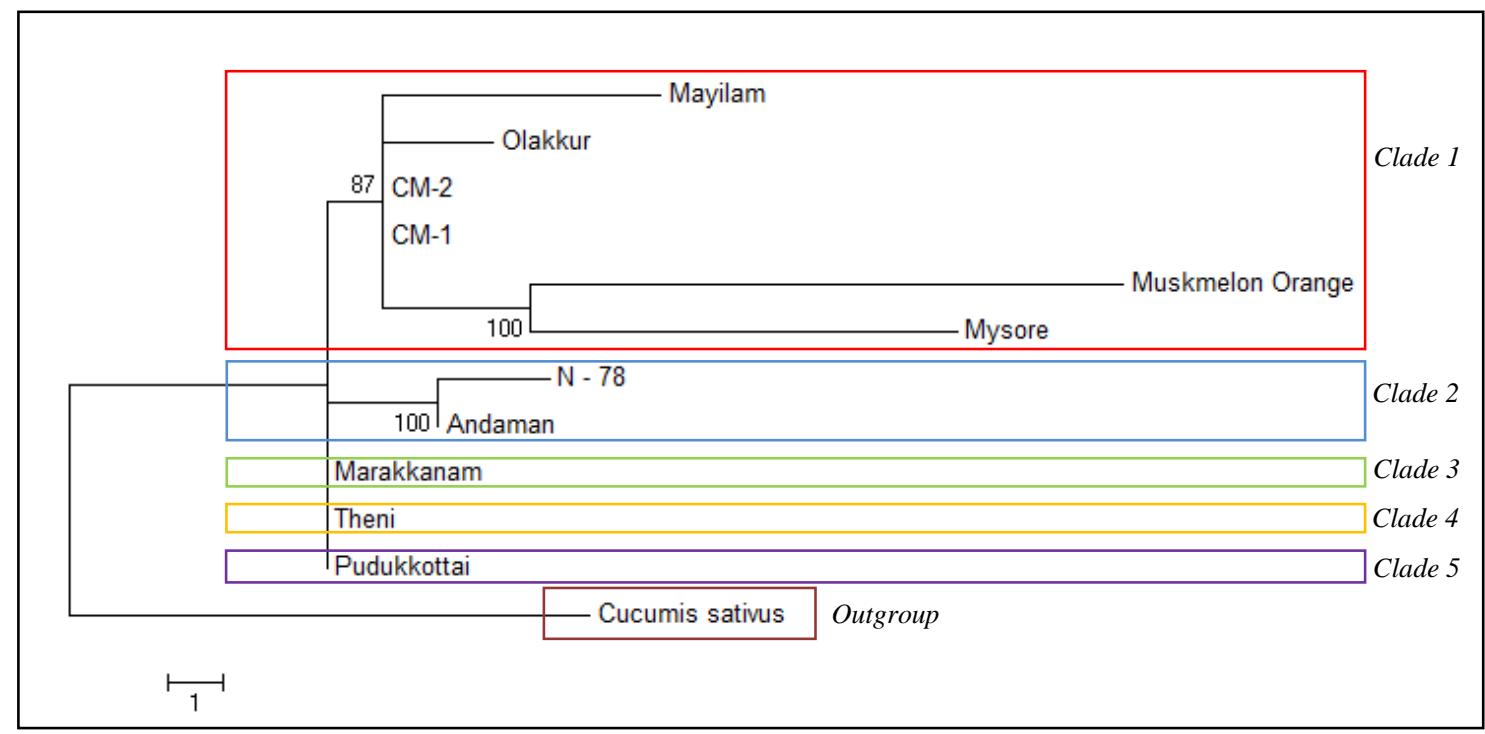

Gambar 2. Pohon filogenetik Cucumis melo L. berdasarkan DNA barcode gen matK menggunakan metode Maximum Parsimony (MP) dengan pengulangan bootstrap 1000 kali

\section{Simpulan dan Saran}

\section{Simpulan}

Pohon filogenetik Cucumis melo L. menunjukkan bahwa beberapa sampel kultivar melon terbagi menjadi lima kelompok/clade besar. Genus Cucumis merupakan kelompok monofiletik dan penggunaan DNA barcode berdasarkan gen matK mampu membedakan variasi intraspesies pada tanaman melon.

\section{Saran}

Analisis filogenetik lanjutan perlu dilakukan dengan memperbanyak sampel kultivar tanaman dari berbagai area geografis dan melibatkan berbagai macam karakter baik fenotip maupun molekular. 


\section{Dewi Retnaningati}

\section{Daftar Pustaka}

Dick, C.W. dan Kress, W.J. 2009. Dissecting tropical plant diversity with forest plots and a molecular toolkit. Bioscience, 59: 745-755.

Frowine, S.A. 2005. Orchids for Dummies. Wiley Publishing, Indianapolis.

Hidayat, T., Kusumawaty, D., Kusdianti, Yati, D.D., Muchtar, A.A. dan Mariana, D. 2008. Analisis Filogenetik Molekuler pada Phyllantus niruri L. (Euphorbiaceae) Menggunakan Urutan Basa DNA Daerah Internal Transcribed Spacer (ITS). Jurnal Matematika dan Sains, 13 (1): 16-21.

Hidayat, Topik, Pancoro, dan Adi. 2008. Ulasan Kajian Filogenetika Molekuler dan Peranannya dalam Menyediakan Informasi Dasar untuk Meningkatkan Kualitas Sumber Genetik Anggrek. Jurnal AgroBiogen, 4 (1): 35-40

Hillis, D.M., Moritz, C. dan Mable, B.K. 1996. Molecular Systematic. 2nd Ed. Sinauer Assocites, Massachusetts.

Jing, Y., Jian-Hua, X. dan Shi-Liang, Z. 2011. New Universal matK Primers for DNA Barcoding Angiosperms. Journal of Systematics and Evolution, 49: 176-181.

Keng, H. 1974. Economic plants of ancient north China as mentioned in Shih ching (Book of Poetry). Econ. Bot., 28: 391-410.

Kolondam, B.J., Lengkong, E., Mandang, J.P., Pinaria, A. dan Runtunuwu, S. 2012. Barcode DNA berdasarkan Gen $r b c L$ dan matK Anggrek Payus Limondok (Phaius tancarvilleae). Jurnal Bioslogos, 2 (2): 17-25.
Lahaye, R., Van der Bank, M., Bogarin, D., Warner, J., Pupulin, F., Gigot, G., Maurin, O., Duthoit, S., Barraclough, T.G. dan Savolainen, V. 2008. DNA barcoding the floras of biodiversity hotspots. Proc. Nat. Acad. Sci., 105 (8): 29232928.

Li, W-H. and Graur, D. 1991. Fundamentals of Molecular Biology. Sinauer Associates. Massachusetts.

Mukherjee, S.K. 1953. Origin, distribution and phylogenetic affinities of the species of Mangifera L. Di dalam: Litz RE, editor. The Mango: Botany, Production and Uses. 2nd Edition. CABI. Massachussets.

Nayar, N.M. dan Singh, R. 1998. Taxonomy, distribution and ethnobotanical uses in Cucurbits (N.M Nayar, and T.A. More, eds.). Science Publishers, Inc., U.S.A. pp 1-18.

Robinson, R.W. dan Decker-Walters, D.S. 1999. Cucurbits. CAB International, New York.

Sobir dan Siregar, F.D. 2010. Budidaya Melon Unggul. Jakarta: Penebar Swadaya.

Tamura, K., Peterson, D., Peterson N., Stecher, G., Nei, M., dan Kumar, S. 2011. MEGA 5: Molecular Evolutionary Genetics Analysis using Maximum Likelihood, Evolutionary Distance, and Maximum Parsimony methods. Molecular Biology and Evolution, 28: 2731-2739.

Xue, C.Y. dan Li, D.Z. 2011. Use of dna barcode sensu lato to identify traditional Tibetan medicinal plant Gentianopsis paludosa (Gentianaceae). J. Sys. Evol, 49 (3): 267-270. 